\title{
THE NON-ARISTOTELIAN VIRTUE OF TRUTH FROM THE SECOND-PERSON PERSPECTIVE
}

\section{ANDREW PINSENT}

\author{
University of Oxford
}

\begin{abstract}
The claim has been made that when Aquinas speaks about the virtue of truth and its opposing vices in the Summa theologiae (ST) 2-2.109-113, he regards himself as speaking of the same virtue of truth as found in the Nicomachean Ethics 4.7. In this paper, I dispute this claim, showing how Aquinas's account cannot be Aristotelian and, in particular, that the possibility of forfeiting the virtue of truth by one serious lie cannot be explained by habituation. I argue instead that Aquinas's account can be better understood by reference to the kind of embodied experience most commonly encountered in joint attention or second-person relatedness, an approach that may offer new ways to address broader moral questions regarding truth.
\end{abstract}

\section{INTRODUCTION}

In Aquinas and the Nicomachean Ethics, a recent book dedicated to the question of how Aquinas deals with and depends on Aristotle's ethics, Kevin Flannery S. J. writes,

In ST 2-2.109, Aquinas introduces what he speaks of as the virtue of truth

(virtus veritatis), which he also calls veracity or truthfulness (veracitas).

Although his account of this virtue goes beyond what Aristotle says in [Nicomachean Ethics] EN 4.7, there can be little doubt that he regards himself as speaking throughout this general section of the Summa of the virtue discussed in that chapter of the Nicomachean Ethics. ${ }^{1}$

In other words, Flannery claims that there is little doubt that when Aquinas speaks about the virtue of truth and its opposing vices in the

\footnotetext{
${ }^{1}$ Kevin Flannery, 'Being truthful with (or lying to) others about oneself', in Aquinas and the Nicomachean Ethics, ed. by Tobias Hoffmann, Jörn Müller and Matthias Perkams (Cambridge; New York: Cambridge University Press, 2013), pp. 129-145 (p. 142).
} 
Summa theologiae (ST) 2-2.109-113, he regards himself as speaking of the same virtue of truth as found in EN 4.7 of the Nicomachean Ethics.

In subsequent paragraphs, Flannery elaborates on why we should have little doubt about this fact, the main points of which I summarise as follows. First, in ST 2-2.109.1, dedicated to the question of whether truth is a virtue, Aquinas immediately cites Aristotle in the sed contra, in particular the fact that Aristotle places truth among the other virtues in the second and fourth book of the Ethics. On this basis, Flannery claims, 'That he [Aquinas] is discussing the EN 4.7 virtue remains his presupposition in all the relevant passages in ST 2-2.109-113'. Second, in ST 2-2.109.1 resp., the object of what Aquinas describes as the virtue of truth, namely truth, matches the core principle that specifies not only the act but also the corresponding virtue in Aristotle's account in EN 4.7, namely that, in itself, 'falsehood is foul and blameworthy, and truth is noble and praiseworthy.' ${ }^{2}$ Third, that Aquinas takes care to relate an expanded sense of truth-telling, such as the 'truth of doctrine', back into the more narrow sense defined explicitly by the scope of the Aristotelian virtue, which is truth in terms of the way one manifests oneself to others (cf. ST 2-2.109.3 ad 3). Hence, Flannery claims, Aquinas understands himself to be speaking in ST 2-2.109.2-3 - and, by implication, throughout ST 2-2.109-113 - about the virtue (and the corresponding act) at the core of EN 4.7. Further to this point, Flannery draws attention to corroborating evidence from ST 2-2.111.3 ad 2, in particular the notion that simplicity and truth-telling are the same thing, understood from different perspectives. ${ }^{3}$ Finally, when considering Augustine's eight-fold division of types of lying in de Mendacio 14.25, Aquinas connects the fourth type 'tucked between the augmenting group and the diminishing group' directly to Aristotle's words in EN 4.7. ${ }^{4}$ The implication seems to be that what Aquinas means by lying 'out of the sheer lust for lying, which proceeds from habit', or what one might described as lying in its 'pure form', is precisely what Aristotle means. Hence, although Flannery concedes that Aquinas says many things in ST 2-2.109-113 that are not found in EN 4.7, 'nor even easily derivable from things that are found there', nevertheless, Aquinas's expanded account 'grows out of the same virtue presented in EN 4.7'.

\footnotetext{
2 Flannery, p. 143.; cf. EN 1127a28-30.

${ }^{3}$ Flannery, p. 144.

${ }^{4}$ Flannery, p. 145.
} 
In this paper, I argue that this conclusion is mistaken. In making this claim, I do not disagree with any of the excellent, finely-honed points of detail to which Flannery draws attention, or indeed any of the steps he makes in his arguments, except the final ones. Moreover, like Flannery, I am impressed with the evident respect that Aquinas has for Aristotle, not least in the way he takes trouble to 'retrofit', one might say, his own expanded notion of truth-telling back into the Aristotelian approach to the matter of the virtue, that is, pertaining to how one presents oneself. I take this fact as indicative of the way in which Aquinas will go to considerable length to agree with Aristotle - if he can do so. Nevertheless, I hold the overall conclusion, that Aquinas regards himself as speaking of the same virtue of truth, or one that at least 'grows out of' the virtue discussed in that chapter of the Nicomachean Ethics, to be mistaken, and for the following reason alone if for no other: what Aquinas normally means by a virtue throughout ST 2-2.1-170 is different in kind from what Aristotle means by a virtue in the Nicomachean Ethics. In other words, Aquinas's account of the virtue of truth cannot be divorced from what he says about virtue in general, an understanding closely related to contemporary work on the second-person perspective and with broader implications for other moral questions about truth and lying.

\section{AQUINAS AND TRUE VIRTUE}

The notion that Aquinas's account of virtue ethics in the Summa theologiae goes beyond what Aristotle says in the Nicomachean Ethics, as indeed Flannery claims about the virtue of truth, is incontrovertible and has long been accepted by scholars. Nevertheless, even to the present day, the extent of their differences has been surprisingly underappreciated. Although I have recently argued this point in detail elsewhere, I present a brief summary here of issues that are pertinent to the present topic. ${ }^{5}$

An initial indication of the distinctiveness of Aquinas's account is that when he introduces the genus of virtue, in ST 1-2.55, he does so in a strikingly non-Aristotelian way,

Virtue is a good quality of the mind, by which we live righteously, of which no one can make bad use, which God works in us, without us. ${ }^{6}$

${ }^{5}$ See especially chapter one of Andrew Pinsent, The Second-Person Perspective in Aquinas's Ethics: Virtues and Gifts (New York; Abingdon, UK: Routledge, 2012).

6 ST 1-2.55.4, 'Virtus est bona qualitas mentis, qua recte vivitur, qua nullus male utitur, quam Deus in nobis sine nobis operator'. This definition is taken from Lombard, 
Aquinas further clarifies that God working virtue 'without us' in this passage does not mean that God infuses virtue in us without our consent. ${ }^{7}$ Nevertheless, as Eleonore Stump has remarked, 'This is manifestly an un-Aristotelian definition, not least because it is impossible to acquire for oneself by practice a disposition that God works in a person without that person'.

Nevertheless, in response to this manifestly non-Aristotelian definition, one might claim that God, in Aquinas's moral universe, merely provides a short cut to the virtue that is so arduously acquired by habituation according to the Nicomachean Ethics. In other words, Aquinas describes the same virtue that Aristotle describes but acquired by different means. Even setting aside the broader problems, however, Aquinas does not permit this interpretation. He agrees that there are indeed some dispositions that are also called virtues and are acquired in the Aristotelian manner by habituation. ${ }^{9}$ What Aquinas means by a perfect virtue, however, is infused by God. ${ }^{10}$ Although these infused virtues may sometimes have the same names as their acquired counterparts, such as 'justice' or 'temperance', they are specifically different in ways that cannot be reduced to diverse origins. ${ }^{11}$ To cite some important examples,

Sent., 2.27.1 no. 1 and draws principally from Augustine, de Libero Arbitrio 2.19. Here and elsewhere in this paper, I use the translation with minor alterations of the Fathers of the English Dominican Province, Thomas Aquinas, The 'Summa Theologica' of St. Thomas Aquinas, Literally Translated by the Fathers of the English Dominican Province (London: Burns, Oates and Washbourne Ltd., 1911-1935). The distinctiveness of Aquinas's approach to the definition of virtue has been pointed out, for example, by Mark Jordan, 'Theology and Philosophy', in The Cambridge Companion to Aquinas, ed. by Norman Kretzmann and Eleonore Stump (Cambridge: Cambridge University Press, 1993), pp. 232-251 (pp. 237-241). As Jordan also points out, this definition is the only one that Aquinas sets out explicitly to defend.

7 ST 1-2.55.4 ad 6, 'Infused virtue is caused in us by God without any action on our part, but not without our consent (virtus infusa causatur in nobis a Deo sine nobis agentibus, non tamen sine nobis consentientibus)'.

${ }^{8}$ Eleonore Stump, 'The Non-Aristotelian Character of Aquinas's Ethics: Aquinas on the Passions', Faith and Philosophy, 28 (2011), 29 - 43 (p. 32).

${ }^{9}$ See, for example, ST 1-2.63.2.

${ }^{10}$ ST 1-2.65.2 resp., 'Only the infused virtues are perfect and are to be called virtues without qualification since they order a human being well toward the ultimate end without qualification (Solae virtutes infusae sunt perfectae, et simpliciter dicendae virtutes, quia bene ordinant hominem ad finem ultimum simpliciter)'.

${ }^{11}$ Aquinas differentiates acquired and infused justice in ST 1-2.100.12, claiming that only the latter is true justice. In ST 1-2.47.14, he distinguishes acquired and infused prudence. In $S T$ 1-2.63.4, he describes acquired and infused temperance as distinct 
these infused dispositions can be possessed by anyone, including young children, are unified by the virtue of love (caritas) rather than prudence alone and can exist with previously acquired contrary dispositions. ${ }^{12}$ Moreover, many of these infused virtues have no Aristotelian counterparts at all, notable examples including faith, hope, love and humility. ${ }^{13}$

Besides these points, a further distinction deserves a special mention, since it throws starkly into relief the non-Aristotelian characteristics and mystery of Aquinas's account of the infused virtues. Aquinas claims that infused virtues are infused all at once, not by a gradual process of repeated good actions. Conversely, the infused virtues can also be lost immediately, not by a gradual process of habituating vice, but through a single seriously evil action or omission termed a 'mortal sin':

For every mortal sin is contrary to love, which is the root of all the infused virtues, as virtues; and consequently, love being banished by one act of mortal sin, it follows that all the infused virtues are expelled (excluduntur) 'as virtues' ... As to the acquired virtues, they are not destroyed by one act of any kind of sin. Accordingly, mortal sin is incompatible with the infused virtues, but is consistent with acquired virtue: while venial [i.e. non-mortal] sin is compatible with virtues, whether infused or acquired. ${ }^{14}$

species of temperance. He also argues explicitly that a difference of efficient cause alone cannot establish a difference of species, cf. ST 1-2.63.4 ad 3, which makes this point by equating the species of sight being given miraculously with sight acquired naturally.

12 Citing especially ST 2-2.47.14, Jean Porter draws attention to Aquinas's claim that anyone, including young children, can have infused virtues. Since these infused virtues include prudence, normally understood as requiring considerable experience and intellectual maturity, this claim further undermines attempts to provide an Aristotelian interpretation of Aquinas's infused virtues. See Jean Porter, 'The Subversion of Virtue: Acquired and Infused Virtues in the "Summa Theologiae", Annual of the Society of Christian Ethics (1992), pp. 19-41 (p. 32). Porter and Bonnie Kent also point out the peculiarity that the infused virtues can co-exist with previously acquired contrary disposition, cf. ibid. p. 30 and Bonnie Kent, 'Does Virtue Make It Easy to Be Good? The Problematic Case of St. Paul', in Les Philosophies Morales et Politiques au Moyen Âge: Actes du IXe Congrès International de Philosophie Médiévale, Ottawa, 17-22 Août 1992, ed. by Bernardo C Bazán, Eduardo Andújar and Leonard G Sbrocchi (Ottawa: Legas, 1995), pp. 723-732 (p. 728).

${ }^{13}$ Cf. ST 2-2.1-46; 161-165.

${ }^{14}$ ST 1a2ae q.71 a.4, 'Quodlibet enim peccatum mortale contrariatur caritati, quae est radix omnium virtutum infusarum, inquantum sunt virtutes, et ideo per unum actum peccati mortalis, exclusa caritate, excluduntur per consequens omnes virtutes infusae, quantum ad hoc quod sunt virtutes ... Virtutes vero acquisitae non tolluntur per unum 
This passage underlines a vital distinction, namely that, according to Aquinas, the infused virtues are 'excluded' or 'cut off' (excluduntur) - in as much as they are virtues - when love is lost by a single serious sin. Hence the word used for such sins is 'mortal', precisely because they kill or extinguish divine love in the soul. Conversely, no acquired virtue can be lost or eradicated by any one action. When stated so plainly, an Aristotelian interpretation of infused virtues is plainly indefensible. Indeed, as Jean Porter has pointed out, even calling infused dispositions 'virtues' is, on this basis, only possible in a carefully qualified sense. ${ }^{15}$ Yet even though such virtues are properly speaking the true virtues, insofar as they are necessary and sufficient for what Aquinas regards as true human flourishing, their importance and characteristics still do not, to my mind, attract sufficient scholarly attention. ${ }^{16}$

Given that the genus of perfect, proper or true virtue is infused, according to Aquinas, the issue that is most pertinent to the correct interpretation of the virtue of truth in ST 2-2.109-113 can be summarised as follows. If the virtue of truth is not an infused virtue or is at least ambiguous, then an Aristotelian interpretation may still be possible. If, however, it is clear that the virtue described in these questions does belong to the infused virtues, that the Aristotelian interpretation is clearly excluded.

\section{AQUINAS AND THE VIRTUE OF TRUTH}

The virtue of truth, as described in ST 2-2.109-113, is a part of a much larger structure of perfective attributes covering the first 170 questions of ST 2-2. Assuming that Aquinas regards himself as presenting a coherent account of human flourishing (and regardless of whether or not he succeeds), an examination of this superstructure can and should provide important clues as to the kinds of perfective dispositions he intends to describe within the specific questions on truth.

actum cuiuscumque peccati. Sic igitur peccatum mortale non potest simul esse cum virtutibus infusis, potest tamen simul esse cum virtutibus acquisitis. Peccatum vero veniale potest simul esse et cum virtutibus infusis, et cum acquisitis.'

15 Porter, p. 20. See also Rebecca Konyndyk DeYoung, 'Power Made Perfect in Weakness: Aquinas's Transformation of the Virtue of Courage', Medieval Philosophy and Theology, 11 (2003), 147-180 (p. 150).

${ }^{16}$ See, for example, ST 2-2.22.7, in which Aquinas claims that no strictly true virtue is possible without the (infused) theological virtue of love, indicating that he considers that acquired dispositions, in the absence of the infused virtues, are not strictly true virtues. 
The virtue of truth is the sixth of nine virtues that Aquinas connects to justice as 'quasi-potential parts' of justice (ST 2-2.80-120), one of three blocks of questions that consider the various parts of justice (ST 2-2.61-79), following on from the treatment of the virtue itself (ST 2-2.57-60). Justice itself is the fifth of seven major virtues that form the largest scale divisions of Aquinas's account of the particular virtues in ST 2-2.1-170. As noted previously, three of these seven major virtues, faith, hope and love (ST 2-2.1-46), have absolutely no Aristotelian counterparts, lending credence from the outset to the view that Aquinas's account of virtues in ST 2-2 as a whole is non-Aristotelian.

The details of Aquinas's account of justice raise still more problems for the Aristotelian interpretation, as can be seen from many of the topics that Aquinas chooses to address under this heading. He examines, for instance, the vices of reviling, detraction, tale-bearing, cursing, simony, as well as the virtues of religion and its acts of devotion, adoration, service, and prayer, including questions about the petitions of the Lord's Prayer and whether God should be praised in song. ${ }^{17}$ These manifestly non-Aristotelian topics make an Aristotelian interpretation awkward at best. Yet the structure of Aquinas's questions on justice exemplifies another peculiarity of his approach, namely that human perfection involves more than simply the acquisition of virtues. After the treatment of the virtue of justice itself, Aquinas appends another disposition, the gift of piety, which is an infused disposition (habitus), but is not an infused virtue. Moreover, after the gift, he mentions two other kinds of perfective attributes: two actualisations of virtue and gifts in the form of promissory sentences called 'beatitudes', and three actualisations called 'fruits' that are described elsewhere as a kind of joyful completion of Aquinas's account of true human perfection. ${ }^{18}$ So Aquinas's account of justice follows the same fourfold pattern that Aquinas first introduces in the $S T$ when he introduces the topic of virtue and its three connected matters: gifts, beatitudes, and fruits. Hence according to Aquinas, his account of the genus of virtue, and the virtue of justice specifically, form only a part of a larger, 'organic' network of virtues, gifts, beatitudes,

17 ST 2-2.72-76, 81-100.

18 The gift of piety and its corresponding beatitudes and fruits are covered in ST 2-2.121. Note that the gift of piety is different from the virtue of piety, which is covered in ST 2-2.101, underlining how the homonymous virtue and gift are distinct habitus. For an interpretation of the role of the gifts, beatitudes and fruits, see chap. 2 and 4 of Pinsent. 
and fruits (VGBF). ${ }^{19}$ In whatever way this network is interpreted, the structure of justice seems to be based on a plan that cannot remotely be described as Aristotelian.

What about the virtue of truth specifically? Can the virtue described in ST 2-2.109-113 be considered the same as that of EN 4.7, despite the many non-Aristotelian characteristics of the broader structure within which these questions are embedded? Certainly there are points of similarity, as Flannery describes, but the differences are also substantial. For example, when Aristotle raises the issue of the dispositions or states of character that are opposed to the virtue of truth, he is referring to vices. By contrast, six of the ten articles of ST 2-2.100-113 are explicitly about whether, and to what extent, the actions of those vices opposed to truth are 'sins'. Moreover, if this difference is explained away simply as the disposition compared to its associated action, it should be added that three of the six articles examine the question of whether the acts associated with these vices are mortal sins. ${ }^{20}$ As noted previously, a characteristic of a single mortal sin, according to Aquinas, is that it expels or cuts off infused virtues (and associated dispositions, including the gifts). The central concern about mortal sins in ST 2-2.100-113 therefore strongly implies that these questions describe the infused virtue of truth, not its Aristotelian counterpart, even if they share certain similar characteristics. In addition, the fact that Aquinas argues explicitly that these mortal sins are opposed to the virtue of truth insofar as they are opposed to the virtue of love (caritas), further underlines that his account of truth is consistent with the principles of his broader account of justice and of virtue generally. ${ }^{21}$ These principles are those of the infused virtues, which are unified by love (caritas) and cut off by mortal sins.

${ }^{19}$ The VGBF structure of Aquinas's approach to human flourishing is first introduced in the preamble of ST 1-2.55, 'We must speak in the first place of the good dispositions, which are virtues, and of other matters connected with them, namely the gifts, beatitudes and fruits (Primo dicendum est de habitibus bonis, qui sunt virtutes et alia eis adiuncta, scilicet dona, beatitudines et fructus). The VGBF structure sets the standard pattern of nearly all the principal virtues of the $S T$, and is described as constituting an organic unity' in Servais Pinckaers, Morality: The Catholic View, trans. by Michael Sherwin (South Bend, Ind.: St. Augustine's Press, 2001), p. 87.

${ }^{20}$ The articles on whether the vices that are opposed to truth are sins are ST 2-2.110.3, 111.1, 113.1; the articles on whether they are (or can also be) mortal sins are ST 2-2.110.4, $111.4,112.2$.

${ }^{21}$ The sins against truth are described as mortal insofar as they are against love (caritas) throughout ST 2-2.109-113. See, for example, ST 2-2.110.4 resp. 
Finally, the dispositions opposed to truth provide another important clue as to the true nature of the virtue being presented. When Aristotle considers the vices opposed to the virtue of truth, he considers only two, boastfulness and mock-modesty, which broadly correspond to the vices that Aquinas describes in ST 2-2.112-113. Nevertheless, Aquinas adds two more vices: 'lying' (110) and dissimulation or hypocrisy (111). These additional vices are not without some importance references to Aristotle on points of detail. But the fact is that the structure as a whole, with four vices instead of two, is different in kind and not merely in degree from Aristotle's account of the virtue of truth and its opposed dispositions. In particular, Aquinas's account of hypocrisy has only a tenuous connection to the issues raised in the Nicomachean Ethics. The principal sources cited in these articles are scripture and patristic texts, notably those of Ambrose, Augustine, Jerome, Gregory, and Isidore. Taken as a whole, these characteristics strongly suggest that the virtue of truth in ST 2-2.109-113 is not acquired in the Aristotelian manner, but belongs to the genus of the infused virtues and their associated perfective attributes, with much of the inspiration drawn from scripture shaped by patristic tradition.

\section{A SECOND-PERSON ACCOUNT OF THE VIRTUE OF TRUTH}

If the virtue of truth is ST 2-2.109-113 draws certain characteristics from Aristotle, as Flannery shows, while still being specifically different, what alternative way do we have to interpret what Aquinas means by this virtue? This question is difficult to answer at least in part because the Nicomachean Ethics has been the 'canonical text' of virtue ethics for most of the last twenty-three centuries, and because Aristotle has provided a commonly accepted and often fairly convincing narrative of how we acquire virtue and vice, namely by a kind of habituation that is similar to the practice of sports, music, and many other activities. ${ }^{22}$ Indeed, this metaphoric understanding is so influential that it is easy to overlook its deficiencies even within the terms of reference of the Nicomachean Ethics. For example, it is not easy to explain how genuine courage can be acquired by habituation. In the case of Aquinas's account of true or

22 The phrase 'canonical text' is from Alasdair MacIntyre, After Virtue: A Study in Moral Theory, Third Edition, 3rd Edition (Notre Dame, Ind.: University of Notre Dame Press, 2007), p. 147. 
perfect virtue, however, even habituation does not assist understanding, as noted previously, since these virtues can be lost or infused immediately. The problem is the lack of an alternative 'root metaphor', denoting an embodied experience according to which the peculiar, apparently ad hoc details of Aquinas's account make sense. ${ }^{23}$ The measure of success for such a metaphor is the number and range of facts that it unifies and makes credible. Without such a metaphor, no matter how many details are stated or inferred, there will be a lack of understanding of what Aquinas means and his account risks remaining incredible.

As I have argued in detail elsewhere, there is, I believe, an alternative embodied experience that makes sense of Aquinas's account, and it is found in surprisingly commonplace situations. Consider, for instance, the virtue of temperance. The Aristotelian account, according to which a mean is selected according to practical wisdom and then practised until it is easy, seems plausible until the question is asked as to how children actually learn to eat and drink in an ordered way. As someone who has many nieces and one nephew, I have observed that as infants they were not good Aristotelians when learning to eat and drink. On the contrary, they first learnt to eat and drink properly in the context of social interaction, such as a contrived game. Indeed these and other children are often far less interested in the food and drink than in the interaction, which the parents obviously use to develop virtue. More specifically, this kind of interaction is one that contemporary experimental psychologists have termed 'joint attention', a working definition of which is 'to share awareness of the sharing of the focus', which is often combined with a sharing of the stance of the other person towards the object of attention. ${ }^{24}$ Joint attention is also closely correlated with (and may be equivalent to) a mode of relatedness first investigated by Martin Buber and Emmanuel Levinas, and which is today called second-personal. ${ }^{25}$

${ }^{23}$ On the importance of metaphor and embodied experience, see Iain McGilchrist, The Master and his Emissary: the Divided Brain and the Making of the Western World (New Haven; London: Yale University Press, 2009), p. 116. The term 'root metaphor' is from Michael Ruse, Science and Spirituality: Making Room for Faith in the Age of Science, 1st edn. (New York: Cambridge University Press, 2010).

${ }^{24}$ This working definition is taken from Peter Hobson, 'What Puts Jointness into Joint Attention?', in Joint Attention: Communication and Other Minds: Issues in Philosophy and Psychology, ed. by Naomi Eilan and others (Oxford: Clarendon Press, 2005), pp. 185-204 (p. 185).

${ }^{25}$ Martin Buber, Ich und Du, 1 aufl. (Leipzig: Insel-Verlang, 1923); Emmanuel Lévinas, Totalité Et Infini: Essai Sur L'Extériorité (London: M. Nijhoff, 1961). 
The relation of parent and child in these virtue-infusing games provides a clue as to what Aquinas is doing in his account of the virtues, except that in Aquinas's case the second-personal agent is God. The key to his account is that the virtues are associated with the gifts, and gifts (when analysed in detail) could be described as 'second-person dispositions'. A gift can be understood metaphorically as enabling a joint attention relation with God, by which a human person participates in God's stance toward various matters. So, for example, the gift of piety appended to justice generates filial affection, according to which a person 'pays worship and duty not only to God, but also to all people on account of their relationship to God'. In other words, by means of the gift of piety, we take on God's stance towards other people as potential or actual sons and daughters, and hence also our potential or actual brothers and sisters. For this reason, I suggest, the infused virtue of justice, to which piety is appended, has a different form to its Aristotelian counterpart. For example, as noted previously, reviling, detraction, tale-bearing and cursing, are not to be found in the Nicomachean Ethics, but are all potential mortal sins in Aquinas's account of justice. These claims makes sense, in the light of this metaphor, because such sins attack those whom God loves as children and so are incompatible with continuing to participate in God's stance and hence God's love. Similarly, the nineteen novel questions on the virtue of religion that Aquinas considers under justice are understandable if the means of growing in virtue to which Aquinas refers is second-person relatedness to God, flourishing in divine friendship. Assuming then that the root metaphor for understanding the virtues and gifts generally is joint attention, how successful is this metaphor for understanding Aquinas's claims about the virtue of truth specifically?

As in the other cases, a successful metaphor will be one that unifies and makes sense of what might otherwise seem to be ad hoc claims. As noted previously, in comparison to the Nicomachean Ethics, Aquinas multiplies the number of vices opposed to truth from two to four. Can this be understood in the light of the root metaphor of joint attention? I think so, for the following reason. In everyday instances of joint attention that also involve use of language, there are several distinct modes of communication with the second person. One can talk about some concrete or abstract object, an object that is also, for the duration of the conversation and at least implicitly, an object of joint attention. One can also talk about oneself from a first-person perspective. One 
can also talk to the second person about the second person, although the latter case arguably reduces to some concrete or abstract object of implicit joint attention, such as 'You looking well', or to some first-person perspective on the other, such as 'I think you are looking well'. Hence the third mode reduces to the first and second modes. Finally, there is non-verbal communication, including, for example, glances, prosody, 'motherese' (in the case of speaking to infants), 'mirroring' and so on. ${ }^{26}$ A good deal of this communication may be subliminal but nevertheless has considerable impact on the sense of union of the persons.

These distinct modes of communication therefore also make distinct kinds of actions possible that are opposed to truthful second-person relatedness oriented towards friendship. With language, one can lie about a concrete or abstract object that is, at least implicitly, an object of joint attention. One can also lie in communicating a first-person account of oneself and one's thoughts. Finally, one can deliberately communicate false impressions to the second person by non-verbal means. These distinctions can, I think, be mapped to the non-Aristotelian complex of vices that Aquinas opposes to the virtue of truth. There is boastfulness and mock-modesty (ST 2-2.112-113), which cover falsehood about oneself, and which are most closely paralleled in Aristotle's account. Nevertheless, Aquinas adds lying, which can be interpreted as falsehood about objects of implicit or explicit joint attention (ST 2-2.110), and hence distinguished from boastfulness and mock-modesty. Finally, there is an important vice that is wholly omitted from Aristotle's account, but which is extremely important to Aquinas and his tradition, namely dissimulation or hypocrisy (ST 2-2.111). According to Aquinas, dissimulation covers actions that are not words but which signify something different to what is in one's mind, in other words non-verbal

${ }^{26}$ There is a vast and rapidly growing literature on non-verbal communication, but a key point to note here is that such communication cannot easily be abstracted from the context of a specific 'I' communicating with a specific 'you', re-emphasising the need to think about language not simply in terms of objective symbol use and organization, but as a communicative interaction between persons. See John T. Nusbaum, 'Language and Communication', in The Oxford Handbook of Social Neuroscience, ed. by Jean Decety and John T. Cacioppo, 1st edn. (New York: Oxford University Press, 2011), pp. 668-679. The irreducibility and importance of prosody and other non-verbal communication has been shown by many methods, for example, by the effects of damage to the right hemisphere's perisylvian region correlated with an impaired ability to use prosody to express emotion (Kenneth M Heilman, Susan A Leon and John C Rosenbek, 'Affective aprosodia from a medial frontal stroke', Brain and language, 89 (2004), 411-416). 
communication. The example he selects from Isidore (Etym. x), also confirms the kind of falsehood Aquinas has in mind, when he says that 'the word hypocrite is derived from the appearance of those who come on to the stage with a disguised face ... so as to deceive the people in their acting. ${ }^{27}$ Hence, rather than an ad hoc list, an account of truth in reference to the metaphor of second-person relatedness can provide an understanding that unifies and makes sense of these multiple vices.

What about the single lie that destroys the virtue of truth? As noted previously, this is perhaps the single most counterintuitive claim from the Aristotelian perspective, since habituation cannot accommodate the instantaneous gain or loss of a disposition. By contrast, even though Aquinas presents an extremely nuanced account of the modes and degrees by which it is possible to sin by falsehood, at least some of these sins can be 'mortal' and hence it is possible to lose the virtue of truth by a single act. But what does this mean? How are we supposed to imagine this is possible?

In general terms and to the best of my knowledge, an account of human flourishing organised round the principle of second-person relatedness, oriented towards friendship, is the only way of making sense of the claim that a virtue can be lost or gained instantly. Acts of betrayal or of reconciliation, unlike habituation, can be singular actions. To give an example, a person can betray his spouse without suddenly losing the habitual dispositions of good living, but such dispositions cease to be effective, as virtues organised towards the flourishing of the relationship, so long as the relationship has not been reconciled. This account makes sense of Aquinas's claim that the infused virtues, but not the acquired dispositions, are 'cut off' (excluduntur) by singular, gravely evil actions. ${ }^{28}$

Within this promising picture overall, the virtue of truth presents a slightly more challenging scenario, however, since betrayal and reconciliation appear to fall more directly under the scope of justice. As Flannery affirms, however, Aquinas follows Aristotle in identifying the virtue of truth simply as that by which a person says what is true. Sins against truth therefore have to be distinguished, at least in principle if not often in practice, from sins against justice. Indeed, on the basis of a commonly accepted definition of lying, 'to make a believed-false statement to another person with the intention that that other person

${ }^{27}$ ST 2-2.111.2 resp.

${ }^{28}$ Cf. Pinsent, p. 75. 
believe that statement to be true, ${ }^{29}$ it is possible for the liar to speak the truth accidentally, doing no apparent injustice to anyone else, and yet still be guilty of lying, perhaps even mortally. How can the second-person perspective shed light on a way to understand these cases?

Recalling that what is 'mortal' about mortal sin is that it cuts off the possibility of second-person relatedness, culminating in friendship, then if there is no external damage, the logical place to look next is internally. In particular, one way of addressing this question, also drawn from the study of the second-person perspective, has been explored by Stump in Wandering in Darkness. In particular, she argues that,

All moral wrongdoing contributes to psychic fragmentation ... This lack of internal integration undermines or obviates closeness between persons. Even God cannot be close to a human being who is internally fragmented and alienated from himself. ${ }^{30}$

On this analysis, wrongdoing in general causes a psychic fragmentation that inhibits friendship, insofar as a person both wills and rejects secondperson union with the other person. Prima facie, it is plausible that lying has an especially destructive effect on psychic union, since what is said (or otherwise communicated to the other) and what is believed are at variance with one another. Hence even if what is said turns out to be true, doing no harm to the other personal agent at all, and therefore doing nothing to erode trust, the liar still plausibly damages himself in a way that damages friendship. To put this issue another way, in a situation of psychic fragmentation, there is no longer a person with a wholly unified psyche with whom one can be friends. As rather disturbing corroboration, it is worth adding that liars can apparently get into a state in which they cannot recognise their own lies. This phenomenon suggests the onset of an internal fragmentation and the loss of a coherent grasp of reality. Moreover, habitual lying is often also associated with narcissism, which is also toxic to friendship. ${ }^{31}$

${ }^{29}$ James Edwin Mahon, 'The Definition of Lying and Deception', in The Stanford Encyclopedia of Philosophy, ed. by Edward N. Zalta, Fall 2008: <http://plato.stanford.edu/ archives/fall2008/entries/lying-definition/> [accessed 27 November 2013].

${ }^{30}$ Eleonore Stump, Wandering in Darkness: Narrative and the Problem of Suffering (Oxford: Clarendon Press, 2010), p. 395.

${ }^{31}$ Salman Akhtar and Henri Parens, Lying, Cheating, and Carrying on: Developmental, Clinical, and Sociocultural Aspects of Dishonesty and Deceit (Lanham, Maryland: Jason Aronson, 2009). 
This analysis suggests that internal fragmentation can destroy the possibility of friendship with a second person, but what about the boundary case of a single lie that remains secret and does no harm? As is well known, singular, external actions can have dramatic moral consequences for relationships, but there may also be a parallel in regard to internal actions. As is commonly experienced and has been verified experimentally many times, 'the act of breaking one's resolve can lead to a general dys-regulation of appetitive behaviour. ${ }^{32}$ In other words, one action can generate a moral transformation. As one way of understanding this, I suggest the following. If a capacity for second-person relatedness is 'hard-wired' into our being, and perhaps even into what it means to be a person, the internal psychic integration of particular persons may work along similar and perhaps derivative lines. ${ }^{33}$ Hence, just as it is possible to break an external relationship by a single act of betrayal, it may be possible to break an internal psychic unity by a single serious lie that is accidentally true and does no external harm. On this basis, even one serious lie could render a person internally disordered, unable fully and honestly to relate in a second-personal way, conducive to friendship, until there has been some kind of reconciliation that enables internal reintegration. This is a topic that would need to be explored in more detail, especially as further research is carried out in experimental psychology and social neuroscience. Nevertheless, an interpretation of Aquinas's

${ }^{32}$ Dylan D. Wagner, Kathryn E. Demos and Todd F. Heatherton, 'Staying in Control: The Neural Basis of Self-regulation and Its Failure', in Decety and Cacioppo eds., The Oxford Handbook of Social Neuroscience, pp. 360-377 (p. 367). Cf. C. P. Herman and D. Mack, 'Restrained and Unrestrained Eating', Journal of personality, 43 (1975), 647-660.

${ }^{33}$ As examples of how second-person relatedness may precede and ground the development of a first-person consciousness, it has been argued that infants are moved to engage in joint attention with others, and even to acquire rudimentary moral perception, even before they have properly formed first-person awareness, some time in their second year. On these and related issues see, for example, M. D. Ferrari and Robert J Sternberg, Self-Awareness: Its Nature and Development (New York: Guilford Press, 1998); Julian Paul Keenan, Gordon G. Gallup and Dean Falk, The Face in the Mirror: The Search for the Origins of Consciousness (New York: Ecco, 2003); Bruce M. Hood, J. Douglas Willen and Jon Driver, 'Adult's Eyes Trigger Shifts of Visual Attention in Human Infants', Psychological Science, 9 (1998), 131-134; Michael L. Kirwan, Lauren K. White and Nathan A. Fox, 'The Emotion-Attention Interface: Neural, Developmental, and Clinical Considerations', in Decety and Cacioppo eds., The Oxford Handbook of Social Neuroscience, pp. 227-242. For recent work on the moral awareness of infants, see Paul Bloom, Just Babies: The Origins of Good and Evil (New York: Crown Publishing Group, 2013). 
account of the virtue of truth in terms of second-person relatedness seems to be far more promising than Aristotelian habituation.

\section{CONCLUSIONS AND IMPLICATIONS}

The indications that the virtue of truth in ST 2-2.109-113 belongs to the category of perfect or infused virtues, as well the doubling of its opposing vices, imply that this virtue is not Aristotelian, despite certain similarities to the corresponding disposition of the Nicomachean Ethics. Moreover, singular actions that exclude virtues, a possibility considered under the category of 'mortal sins' in ST 2-2.110-113 are incompatible with the 'root metaphor' of Aristotelian virtue ethics, namely habituation.

By contrast, an understanding of the virtue of truth in terms of joint attention or second-person relatedness can accommodate and unify these claims. In particular, the diverse kinds of interpersonal communication involved in second-person relatedness give rise to diverse possibilities for falsehood that can be mapped to the vices that Aquinas lists in these questions. Moreover, the notion that a relationship can be betrayed or reconciled, possibly even when the relationship is between parts of one's own psyche, may also provide a way to understand Aquinas's single most puzzling claim, namely that it is possible for perfect virtues, including truth, to be 'cut off' or restored as virtues by singular actions. In these questions, as elsewhere in ST 2-2.1-170, the metaphor that gives insight into Aquinas's claims is joint attention with a second person, not habituation as in the Aristotelian case.

For Aquinas, the principal second-person agent is God, but the general idea of forms of virtue being infused by second-person relatedness has implications beyond this specific theological context. For example, if lying is always wrong, as both Aristotle and Aquinas claim, this has proved a hard position to defend today, ultimately because in many ethical frameworks, the good of truth-telling is only related by a fairly long causal chain to some ultimate good, a connection that is apparently broken in hard cases. By contrast, the virtue ethics of Aquinas may be one example of a way in which truth-telling and human flourishing are more inherently linked, since second-person relatedness properly requires a personal integration that is damaged or destroyed by falsehood. As research into second-person relatedness continues, this approach to truth will warrant further investigation. 
Acknowledgments. I am grateful to Eleonore Stump for the opportunity to discuss some of the ideas presented in this paper at an earlier stage of their development. The final stages of this work were also made possible through the generous support of a grant from the John Templeton Foundation.

\section{BIBLIOGRAPHY}

Akhtar, Salman, and Henri Parens, Lying, Cheating, and Carrying on: Developmental, Clinical, and Sociocultural Aspects of Dishonesty and Deceit (Lanham, Maryland: Jason Aronson, 2009)

Aquinas, Thomas, The 'Summa Theologica' of St. Thomas Aquinas, Literally Translated by the Fathers of the English Dominican Province (London: Burns, Oates and Washbourne Ltd., 1911-1935)

Bloom, Paul, Just Babies: The Origins of Good and Evil (New York: Crown Publishing Group, 2013)

Buber, Martin, Ich und Du, 1st edn. (Leipzig: Insel-Verlang, 1923)

DeYoung, Rebecca Konyndyk, 'Power Made Perfect in Weakness: Aquinas's Transformation of the Virtue of Courage', Medieval Philosophy and Theology, 11 (2003), 147-180

Ferrari, M. D, and Robert J Sternberg, Self-Awareness: Its Nature and Development (New York: Guilford Press, 1998)

Flannery, Kevin, 'Being Truthful With (or Lying to) Others About Oneself', in Aquinas and the Nicomachean Ethics, ed. by Tobias Hoffmann, Jörn Müller and Matthias Perkams (Cambridge; New York: Cambridge University Press, 2013), pp. 129-145

Heilman, Kenneth M, Susan A Leon, and John C Rosenbek, 'Affective Aprosodia from a Medial Frontal Stroke', Brain and Language, 89 (2004), 411-416.

Herman, C P, and D Mack, 'Restrained and Unrestrained Eating', Journal of Personality, 43 (1975), 647-660

Hobson, Peter, 'What Puts Jointness into Joint Attention?', in Joint Attention: Communication and Other Minds: Issues in Philosophy and Psychology, ed. by Naomi Eilan, Christoph Hoerl, Teresa McCormack and Johannes Roessler (Oxford: Clarendon Press, 2005), pp. 185-204

Hood, Bruce M., J. Douglas Willen, and Jon Driver, 'Adult's Eyes Trigger Shifts of Visual Attention in Human Infants', Psychological Science, 9 (1998), 131-134 Jordan, Mark, 'Theology and Philosophy', in The Cambridge Companion to Aquinas, ed. by Norman Kretzmann and Eleonore Stump (Cambridge: Cambridge University Press, 1993), pp. 232-251

Keenan, Julian Paul, Gordon G Gallup, and Dean Falk, The Face in the Mirror: The Search for the Origins of Consciousness (New York: Ecco, 2003) 
Kent, Bonnie, 'Does Virtue Make It Easy to Be Good? The Problematic Case of St. Paul', in Les Philosophies Morales et Politiques au Moyen Âge: Actes du IXe Congrès International de Philosophie Médiévale, Ottawa, 17-22 Août 1992, ed. by Bernardo C Bazán, Eduardo Andújar and Leonard G Sbrocchi (Ottawa: Legas, 1995), pp. 723-732

Kirwan, Michael L., Lauren K. White, and Nathan A. Fox, 'The EmotionAttention Interface: Neural, Developmental, and Clinical Considerations', in The Oxford Handbook of Social Neuroscience, ed. by Jean Decety and John T. Cacioppo, 1st edn. (New York: Oxford University Press, 2011), pp. 227-242

Decety, Jean, and John T. Cacioppo, eds., The Oxford Handbook of Social Neuroscience, 1st edn. (New York: Oxford University Press, 2011)

Lévinas, Emmanuel, Totalité Et Infini: Essai Sur L'Extériorité (London: M. Nijhoff, 1961)

MacIntyre, Alasdair, After Virtue: A Study in Moral Theory, 3rd Edition (Notre Dame, Ind.: University of Notre Dame Press, 2007)

Mahon, James Edwin, 'The Definition of Lying and Deception', in The Stanford Encyclopedia of Philosophy, ed. by Edward N. Zalta, Fall 2008: <http://plato. stanford.edu/archives/fall2008/entries/lying-definition/> [accessed 27 November 2013]

McGilchrist, Iain, The Master and his Emissary: The Divided Brain and the Making of the Western World (New Haven; London: Yale University Press, 2009)

Nusbaum, John T., 'Language and Communication', in The Oxford Handbook of Social Neuroscience, ed. by Jean Decety and John T. Cacioppo, 1st edn (New York: Oxford University Press, 2011), pp. 668-679

Pinckaers, Servais, Morality: The Catholic View, trans. by Michael Sherwin (South Bend, Ind.: St. Augustine's Press, 2001)

Pinsent, Andrew, The Second-Person Perspective in Aquinas's Ethics: Virtues and Gifts (New York; Abingdon, UK: Routledge, 2012)

Porter, Jean, 'The Subversion of Virtue: Acquired and Infused Virtues in the "Summa Theologiae", Annual of the Society of Christian Ethics (1992), pp. 19-41

Ruse, Michael, Science and Spirituality: Making Room for Faith in the Age of Science, 1st edn. (New York: Cambridge University Press, 2010)

Stump, Eleonore, 'The Non-Aristotelian Character of Aquinas's Ethics: Aquinas on the Passions', Faith and Philosophy, 28 (2011), 29 - 43

Stump, Eleonore, Wandering in Darkness: Narrative and the Problem of Suffering (Oxford: Clarendon Press, 2010)

Wagner, Dylan D., Kathryn E. Demos, and Todd F. Heatherton, 'Staying in Control: The Neural Basis of Self-Regulation and Its Failure', in The Oxford Handbook of Social Neuroscience, ed. by Jean Decety and John T. Cacioppo, 1st edn (New York: Oxford University Press, 2011), pp. 360-377 